\title{
Investigation of the Anodic Dissolution of Zinc in Sodium Chloride Electrolyte - A Green Process
}

\author{
Ibrahim M. Ismail, ${ }^{a, *}$ Omar E. Abdel-Salam, ${ }^{a}$ Tamer S. Ahmed, ${ }^{a}$ Ahmed \\ Soliman, ${ }^{a}$ Ibrahim A. Khattab ${ }^{b}$ and Meshaal F. Al-Ebrahim ${ }^{b}$ \\ ${ }^{a}$ Department of Chemical Engineering, Faculty of Engineering, Cairo University, Giza, Egypt \\ ${ }^{b}$ National Research Center, Dokki, Giza, Egypt
}

Received 30 January 2013; accepted 12 August 2013

\begin{abstract}
The anodic dissolution of zinc electrodes in sodium chloride aqueous solution has been investigated experimentally. The effects of application of polarity reversal (PR), ultrasonic (US) enhancement, stirring, current density (CD), concentration and $\mathrm{pH}$ of the supporting electrolyte, and temperature of the bath were studied. The results revealed that application of PR increased the dissolution of $\mathrm{Zn}$ but the current was low. However, the application of US enhancement led to higher zinc dissolution accompanied with higher current efficiency (CE). The combination of US enhancement and stirring led to more dissolution of zinc. Increasing the current density and concentration of $\mathrm{NaCl}$ increased the dissolution of zinc and the current efficiency was almost constant. On the other hand, $\mathrm{pH}$ of the bath did not play a significant effect on the amount of the dissolved zinc or current efficiency. It was also observed that increasing the temperature from $10{ }^{\circ} \mathrm{C}$ to $40{ }^{\circ} \mathrm{C}$ led to a significant increase in the mass of the dissolved zinc and $\mathrm{CE}$; but the increase of temperature from $40{ }^{\circ} \mathrm{C}$ to 50 or $60{ }^{\circ} \mathrm{C}$, however, did not have a significant effect.
\end{abstract}

Keywords: zinc, electrolyte, anodic dissolution, green process.

\section{Introduction}

Inorganic metal compounds are very important in chemical industries especially, e.g., in plating industry, painting, pigments production, polishing materials production, cosmetics industries. Chemical dissolution of metals is considered as the most important step in the production of pure metal salts [1]. However, the use of active reagents currently utilized in the dissolution process has several

\footnotetext{
* Corresponding author. E-mail address: dr_ismail@instruchem.org
} 
disadvantages, such as: production of vapors or fumes, which requires complicated and troublesome trapping arrangements and neutralizations, extensive energy consumption, long time for metal dissolution, and the use of special materials of construction for equipment due to the strong corrosiveness of the dissolution medium. In order to overcome these disadvantages, electrolytic metal dissolution may introduce a realistic solution.

The process of selective anodic dissolution of a metal does not have the disadvantages mentioned above. In essence, the metal is treated electrolytically as an anode, by utilizing a rapid-action electrolyte of a composition which is substantially independent of the duration of the operation of the dissolution. Several inorganic compounds may be produced by the above mentioned anodic dissolution process, such as zinc sulfate, zinc oxide, zinc chloride, copper sulfate, copper oxide, copper cyanide, nickel sulfate, etc. Each of these compounds has wide industrial applications [2].

Zinc is ranked as the 23rd most common element in the earth's crust, amounting to $0.013 \%$. However, it ranks fourth among the metals in worldwide production and consumption [3]. The uses of zinc can be divided into six major categories: (i) coatings; (ii) casting alloys; (iii) alloying element in brass and other alloys; (iv) wrought zinc alloys; (v) zinc oxide; and (vi) zinc chemicals [4]. The most important application of zinc is a coating for steel corrosion protection. In addition, zinc is an important component in paints, cosmetics, pharmaceuticals, storage batteries, electrical equipment and an endless list of other capital applications [5-7]. As a result of its importance, the zinc corrosion and electrochemistry have been studied extensively [8-19] and reviewed thoroughly up to year 1996 by Zhang [4]. Moreover, many investigations have been conducted to determine the kinetic and thermodynamic characteristics of zinc electrode system. Extensive bibliographies of this work appear in the literatures $[10,16]$.

The dissolution of zinc was studied extensively through the last four decades [8,18-50]. The anodic dissolution of zinc has been investigated in different electrolyte media. Some examples are: in potassium hydroxide solutions [22-29], in potassium hydroxide in presence of sodium metasilicate [30], in potassium hydroxide in presence of carbonate ions [31], in potassium hydroxide in presence of $\mathrm{ZnO}$ [32], in sodium hydroxide solutions [33-35], in sodium hydroxide in presence of sodium silicate and sodium tetraborate [13], in sodium hydroxide in presence of sulfur containing ions such as $\mathrm{Na}_{2} \mathrm{SO}_{4}, \mathrm{Na}_{2} \mathrm{SO}_{3}, \mathrm{Na}_{2} \mathrm{~S}, \mathrm{Na}_{2} \mathrm{~S}_{2} \mathrm{O}_{3}$ or $\mathrm{NH}_{4} \mathrm{SCN}$ [36], in saturated zinc sulfate solution [37], in aerated sodium sulfate solutions [38,39], in $\mathrm{NH}_{4} \mathrm{Cl}$ and/or $\mathrm{NH}_{4} \mathrm{Cl} / \mathrm{ZnCl}_{2}$ solutions [40,41], in $\mathrm{NH}_{4} \mathrm{Cl}+$ $\mathrm{NiCl}_{2}$ and $\mathrm{NH}_{4} \mathrm{Cl}+\mathrm{NiCl}_{2}+\mathrm{ZnCl}_{2}$ electrolytes [42], in $\mathrm{H}_{3} \mathrm{BO}_{3} / \mathrm{NH}_{4} \mathrm{Cl} / \mathrm{Na}_{2} \mathrm{SO}_{4}$ [43], in aqueous-methanolic trichloracetic acid solutions [44], in ammoniacal ammonium chloride system [45], in potassium nitrate solution [46], in aqueous salt solutions such as $\mathrm{Cl}^{-}, \mathrm{Br}^{-}, \mathrm{I}^{-}, \mathrm{Ac}^{-}, \mathrm{SO}_{4}{ }^{2-}$ and $\mathrm{NO}_{3}{ }^{-}$[47], in sulfamic acidformamide solution [48], in EDTA solution [49], in sodium borate solutions with or without $\mathrm{Na}_{2} \mathrm{SO}_{4}, \mathrm{Na}_{2} \mathrm{~S}_{2} \mathrm{O}_{3}$ or $\mathrm{Na}_{2} \mathrm{~S}$ as aggressive agents [50], solutions saturated with carbon dioxide under elevated pressure [51], and even in tap water [52]. 
The corrosion and electrochemical studies of zinc dissolution in sodium chloride solutions have been investigated in the literatures [14,17-19]. For $\mathrm{pH}>12$, a passive layer composed of zinc hydroxide and/or zinc oxide is formed on the surface of the zinc sample [19]. In an aerated acidic $\mathrm{NaCl}$ solution, the complexity of the layer formed on zinc sample exposed to $\mathrm{NaCl}$ media makes the corrosion mechanism of zinc difficult to be understood. It forms a complex layer composed from zinc oxide, zinc hydroxide and zinc hydroxide chloride or simonkolleite; $\mathrm{Zn}_{5}(\mathrm{OH})_{8} \mathrm{Cl}_{2} \cdot 2 \mathrm{H}_{2} \mathrm{O}$. The zinc hydroxide chloride and zinc oxide are the dominant corrosion products [53]. In ambient $\mathrm{CO}_{2}$ levels, zinc hydroxide carbonate or hydrozincite; $\left(\mathrm{Zn}_{5}(\mathrm{OH})_{6}\left(\mathrm{CO}_{3}\right)_{2} \bullet \mathrm{H}_{2} \mathrm{O}\right.$ were additionally observed [54], with the major compounds being zinc hydroxide chloride and zinc hydroxide carbonate [55].

On the other hand, the chemical applications of ultrasound (US), "sonochemistry", has become an exciting new field of research during the past decades [56]. Moreover, the application of US in electrolytic cell has been reported to help in depassivation of the electrodes with a huge effect on the mass transport at the electrode surface [57].

In order to design an industrial unit or even a pilot unit for the electrolytic production of zinc compounds, the operating conditions of the electrolytic anodic dissolution of the zinc metal sources of these compounds have to be thoroughly investigated. In this paper, the effects of the application of US and polarity reversal (PR) and other operating parameters such as current density, concentration of electrolyte, $\mathrm{pH}$, temperature, and stirring on the anodic dissolution of zinc in $\mathrm{NaCl}$ are presented.

\section{Experimental}

\section{Surface pretreatment}

All chemicals used in surface treatment were of analytically pure grades. Six operations were carried out on the surface of zinc substrate. These operations were: mechanical polishing with two different sand papers down to 4/0 grade, degreasing with solvent, degreasing with alkali solution, pickling, and chemical polishing. These operations were done in order to obtain high smooth surface free from oil, grease and scales and to avoid defects such as peeling, blistering, or poor distribution of the metal on the surface of the electrode. To remove grease, oils, waxes and fats introduced into the metal either from fabrication, stamping, pressing, or polishing, degreasing was done by using solvent cleaners and alkali soaking cleaners. Degreasing with solvent was accomplished using acetone, which possesses all the requirements necessary to ideal degreasing practices because of its ease of application and its great penetrating power. As for alkali soaking, we got a cleaner solution consisting of sodium hydroxide $50 \mathrm{~g} / \mathrm{L}$, sodium carbonate $20 \mathrm{~g} / \mathrm{L}$, trisodium phosphate $20 \mathrm{~g} / \mathrm{L}$, and sulfonic acid $2 \mathrm{~g} / \mathrm{L}$ dissolved in bi-distilled. Degreasing was ensured by washing the metal with water, and the presence of a continuous unbroken film of water over the zinc substrate indicates the complete removal of greases. 
To remove oxides and scales, the zinc substrate was pickled with a solution consisting of $400 \mathrm{~g} / \mathrm{L}$ nitric acid and $5 \mathrm{~g} / \mathrm{L}$ hydrofluoric acid in bi-distilled water. Finally, to ensure smooth surface, the zinc substrates were chemically polished by immersing the substrates in $100 \mathrm{~g} / \mathrm{L}$ oxalic acid solution and were allowed to boil for 5 minutes.

\section{Preparation of electrolyte solution}

All materials used in the electrolyte preparation for the anodic dissolution of zinc metal were of analytical grade. The sodium chloride supporting electrolyte was weighed and dissolved in bi-distilled water to the desired concentration and then $\mathrm{pH}$ adjustment was carried out to make the solution ready for the electrolysis process. Hydrochloric acid and sodium hydroxide were used for the $\mathrm{pH}$ adjustment. Zinc metal for the dissolution process was of high purity (99.99\%). This zinc was imported from Germany.

\section{Experimental setup}

Fig. 1 shows the inside details of the electrolytic cell. The setup consisted of:

- D.C. power supply: a regulated D. C. power source (Lodestar 8203) capable to supplying up to $10 \mathrm{~A}$ and $30 \mathrm{~V}$ was used to supply electric power. During each experiment the current could be kept constant by manual regulation.

- Mechanical stirrer: had a fixed speed of $200 \mathrm{rpm}$.

- Polarity reversal: a back-switch polarity reversal piece was used to reverse electrode polarity during the electrolysis process. The reversal time was adjusted manually.

- pH meter: (type HI 8417 made by HANNA Instruments) of a resolution 0.01 was used to measure the $\mathrm{pH}$ of the electrolyte solution.

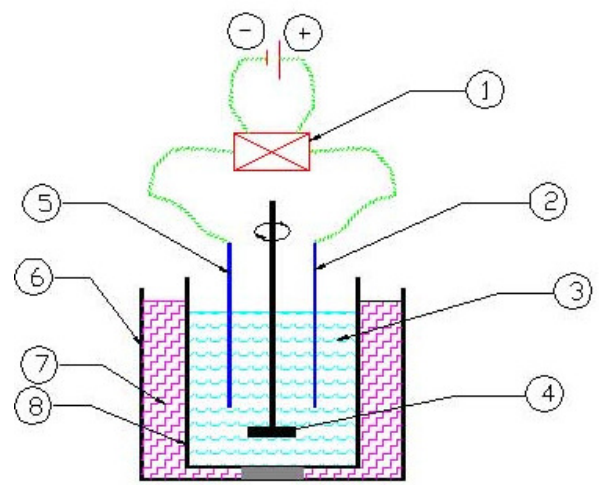

Figure 1. Details of the experimental setup for the anodic dissolution of zinc. 1Polarity reverser, 2- Zinc anode, 3- Supporting electrolyte, 4- Mechanical stirrer, 5Zinc cathode, 6- Source of ultrasonic waves, 7- Water bath, 8- Glass container, 9- D.C. power supply.

\section{Experimental procedure}

The electrolysis cell was cleaned, washed and filled with the electrolyte to the desired level to ensure complete submerging of the electrodes. In this cell, zinc substrate was used as anode. During some experiments the direct current pathway was reversed to the opposite direction and consequently the cathode was 
made of zinc metal. The reversal of the polarity was expected to help in the prevention of the formation of a passive film on the surface of the anode. In addition, the use of US was expected to repel off the formed passive layer to the bulk of the solution. All of the above may minimize the current drop and maintain the current efficiency of the zinc dissolution as high as possible. The zinc substrate was weighed before and after each dissolution experiment and from the weight difference the weight of the dissolved zinc metal was determined.

\section{Results and discussion}

\section{Anodic dissolution of Zn without the application of PR, US or stirring}

Fig. 2 shows the change of the current passing in the cell at a potential of $2.8 \mathrm{~V}$ without the application of US, PR or stirring. The electrolyte consisted of 90 $\mathrm{g} / \mathrm{dm}^{3}(\sim 1.5$ mole/L) sodium chloride solution. The $\mathrm{pH}$ was adjusted using sodium hydroxide to value of 13. The time of electrolysis was 120 minutes. The average current passing through the cell was calculated from the area under the curve divided by 120 minutes, as $0.436 \mathrm{~A}$. The dissolved $\mathrm{Zn}$ was $1.0634 \mathrm{~g}$, and the current efficiency (CE) was 99.94\%. The high CE may be attributed to the small value of the average current passing at this potential, and the dissolution was significant at the early period after the application of potential. After this effective period, the passing current decreased due to the formation of the passive layer on the surface of the anode.

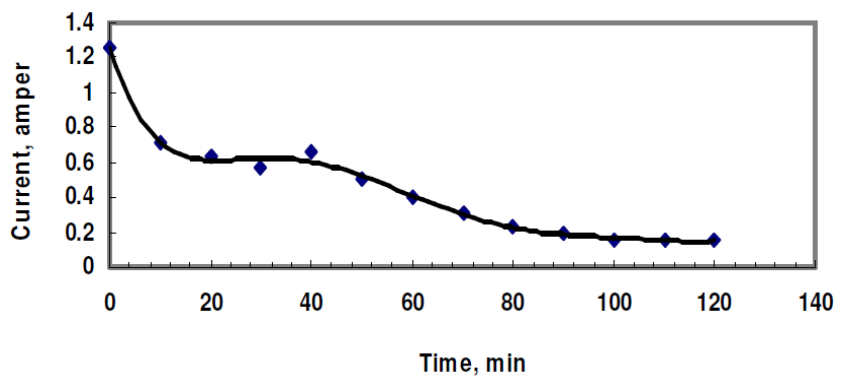

Figure 2. Current versus time under the following conditions: applied potential: $2.8 \mathrm{~V}$, pH: $13, \mathrm{NaCl}$ conc.: $90 \mathrm{~g} / \mathrm{dm}^{3}$, initial temp. $25^{\circ} \mathrm{C}$; no application of US, PR, or stirring.

This layer was $\mathrm{ZnO}$ only as indicated by the results of X-Ray Diffraction (XRD). The analysis is shown in Table 1. No trace of zinc hydroxide chloride was observed from the XRD data for the current passivation layer. Usually in the literature, for alkaline solutions, the passivation layer consists predominantly of zinc hydroxide chloride or zinc oxide [19,53].

\section{Effects of simultaneous application of PR, US and stirring}

In Table 2, the effects of simultaneous application of PR, US and stirring on the dissolved zinc and CE are presented. These effects, especially using US, help in minimizing the effect of passivation [57]. In all experiments, the operating parameters were kept the same as indicated in the title of the table. 
Table 1. XRD analysis of the white material formed in the cell.

\begin{tabular}{|c|c|c|}
\hline Observed d-spacing & Reference d-spacing & Phase \\
\hline 2.81906 & 2.8144 & $\mathrm{ZnO}$ \\
\hline 2.60635 & 2.6033 & $\mathrm{ZnO}$ \\
\hline 2.47825 & 2.490 & $\mathrm{ZnO}$ \\
\hline 1.91309 & 1.9051 & $\mathrm{ZnO}$ \\
\hline 1.62629 & 1.6208 & $\mathrm{ZnO}$ \\
\hline 1.4786 & 1.4723 & $\mathrm{ZnO}$ \\
\hline 1.37968 & 1.3745 & $\mathrm{ZnO}$ \\
\hline 1.35911 & 1.3549 & $\mathrm{ZnO}$ \\
\hline
\end{tabular}

Table 2. Effects of simultaneous application of PR, US and stirring. Operating conditions: applied voltage $=2.8 \mathrm{~V} ; \mathrm{NaCl}$ conc. $=90 \mathrm{~g} / \mathrm{L} ; \mathrm{pH}=13$; initial temp. $=25$ ${ }^{\circ} \mathrm{C}$.

\begin{tabular}{|l|c|c|c|}
\hline \multicolumn{1}{|c|}{ Mode of operation } & Dissolved Zn, g & Average current, A & Current efficiency \\
\hline -No US, PR or stirring & 1.0634 & 0.43625 & $99.94 \%$ \\
\hline $\begin{array}{l}\text {-No US or stirring } \\
\text { - use of PR every 2 min. }\end{array}$ & 1.7425 & 1.349 & $52.936 \%$ \\
\hline $\begin{array}{l}\text { - No stirring or PR } \\
\text { - Use of US }\end{array}$ & 3.606 & 1.5741 & $93.92 \%$ \\
\hline $\begin{array}{l}\text { - No stirring - Use of US \& } \\
\text { PR every 2 min. }\end{array}$ & 2.4279 & 1.7017 & $58.497 \%$ \\
\hline $\begin{array}{l}\text { - No PR } \\
\text { - Use of US \& stirring }\end{array}$ & 3.929 & 1.616 & $99.68 \%$ \\
\hline
\end{tabular}

When the polarity was reversed every 2 minutes, without the application of US enhancement or stirring, the mass of dissolved zinc was $1.7425 \mathrm{~g}$ and the average current was 1.349 A. Clearly, the application of polarity reversal led to more dissolution of zinc as the passing current was not steadily decreased, as in the case of Fig. 2. This might be due to the smaller thickness of the solid layer formed at the surface of the anode by the effect of polarity reversal. However, the color of produced solid was slightly darker than the color of the solid produced in the run of Fig. 2.

At the end of the experiment, it was observed that a black layer was formed at the surface of the cathode. The formation of this black layer on zinc electrode was also reported by Cachet et al. [39]. When this layer was peeled off the cathode and left for some time in the atmospheric air, it was turned to light grey color. The result of XRD analysis of this grey powder shown in Table 3 indicated the presence of free zinc metal and zinc oxide. The existence of zinc with zinc oxide was also observed by other investigator [58]. The CE was unexpectedly low and had a value of 52.94\%. This low CE may be attributed to the fact that there was a time lag between the commencement of polarity reversal and the 
recommencement of the dissolution process. During this time lag no gases were observed to evolve at the cathode.

Table 3. XRD analysis of the grey layer formed at the cathode.

\begin{tabular}{|c|c|c|}
\hline Observed d-spacing & Reference d-spacing & Phase \\
\hline 2.81443 & 2.8144 & $\mathrm{ZnO}$ \\
\hline 2.60151 & 2.6033 & $\mathrm{ZnO}$ \\
\hline 2.47558 & 2.473 & $\mathrm{Zn}$ \\
\hline 2.09004 & 2.091 & $\mathrm{Zn}$ \\
\hline 1.91084 & 1.9111 & $\mathrm{ZnO}$ \\
\hline 1.62588 & 1.6249 & $\mathrm{ZnO}$ \\
\hline 1.47885 & 1.4772 & $\mathrm{ZnO}$ \\
\hline 1.3786 & 1.3784 & $\mathrm{ZnO}$ \\
\hline 1.36096 & 1.342 & $\mathrm{Zn}$ \\
\hline
\end{tabular}

When US enhancement was only applied at the same operating conditions, the average current was $1.574 \mathrm{~A}$, the dissolved $\mathrm{Zn}$ was $3.606 \mathrm{~g}$, and the $\mathrm{CE}$ was $93.92 \%$. It was observed that at the end of the experiment the temperature of the bath increased to about $55^{\circ} \mathrm{C}$ in spite the initial temperature was about $25^{\circ} \mathrm{C}$. Hence, the application of ultrasonic enhancement led to higher zinc dissolution accompanied with higher CE.

Both US and PR every 2 minutes were applied while other operating parameters were kept constant. The average current was estimated as $1.702 \mathrm{~A}$, dissolved Zn was $2.4279 \mathrm{~g}$, and the CE was $58.497 \%$. This indicates that the application of PR had a drawback effect on the dissolution process of $\mathrm{Zn}$. This drawback effect may be a result of the time elapsed before the reaction got started after the reversing of polarity. It may be deduced that $\mathrm{PR}$ is not advantageous when used alone or when combined with US.

Finally, during the application of the combination of US and stirring, the average current was $1.616 \mathrm{~A}$, dissolved $\mathrm{Zn}$ was $3.929 \mathrm{~g}$, and the CE was 99.68. However the powder was not as white as, for instance, the powder produced in the experiment of Fig. 2. The rise in the temperature of the bath during the run of the experiment was also observed.

\section{Effect of Current Density (CD)}

Fig. 3 indicates that the mass of the dissolved zinc is increasing with the increase in $\mathrm{CD}$. It was not possible to increase CD beyond the largest value shown in the graph due to a limitation imposed by the power supply. Fig. 4, however, indicates that no significant increase of $\mathrm{CE}$ was observed with the increase in CD under the conditions of Fig. 3. The $\mathrm{CE}$ is high enough to confirm that most of the electricity was used to dissolve zinc. 


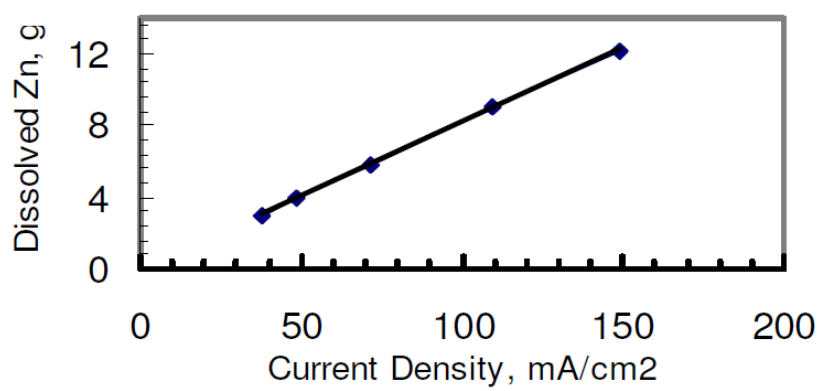

Figure 3. Effect of current density on anodic dissolution of zinc under the following conditions: application of US and stirring; cathode is made of stainless steel; $\mathrm{NaCl}$ concentration $=90 \mathrm{~g} / \mathrm{L} ;$ starting temperature $=25^{\circ} \mathrm{C} ; \mathrm{pH}=13$.

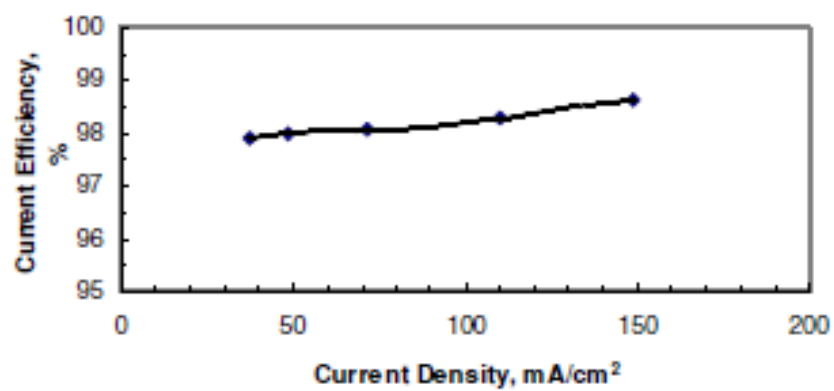

Figure 4. Effect of current density on current efficiency.

\section{Effect of supporting electrolyte concentration}

Fig. 5 and 6 illustrate the effect of concentration of the supporting electrolyte on the amount of dissolved Zinc and CE, respectively. The experiments were performed under the following conditions: application of US, stainless steel cathode, $\mathrm{pH}=13$, starting applied potential $=5.5 \mathrm{~V}$, and starting temperature $=$ $25{ }^{\circ} \mathrm{C}$. The amount of dissolved zinc, as shown in Fig. 5, increased as the concentration of $\mathrm{NaCl}$ was increased from $30-150 \mathrm{~g} / \mathrm{dm}^{3}$. This may be a result of the increased concentration of chloride ions, which are aggressive to the passive layer formed at the anode surface, with respect to hydroxide ions that are inhibitive ions, i.e., lead to the formation of the passive layer $[4,17]$. Therefore at high concentration of chloride ions, the breakdown of the passive layer is easier and new surface of zinc anode was subjected to dissolution [17].

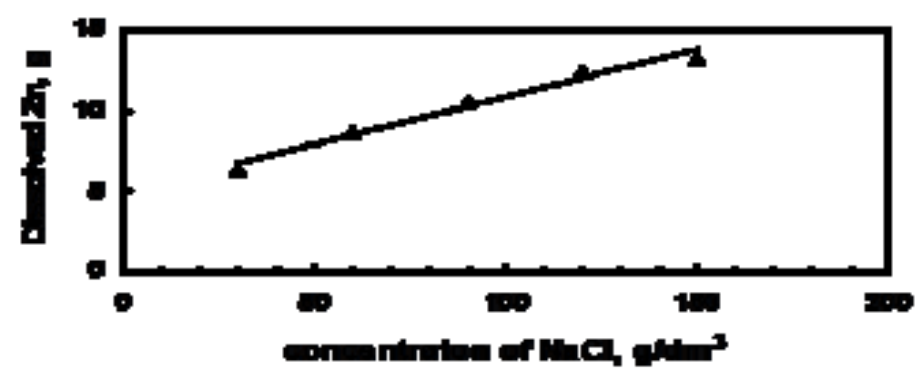

Figure 5. Effect of the concentration of supporting electrolyte on anodic dissolution of zinc. 
On the other hand the current efficiency was essentially the same and had a value around 98\%, as shown in Fig. 6. During these experiments it was observed that the passing current, i.e., the current density, increased with increasing the concentration of the supporting electrolyte at the same applied potential. This may be a result of the increase in conductivity of the electrolyte with increasing the concentration of $\mathrm{NaCl}$.

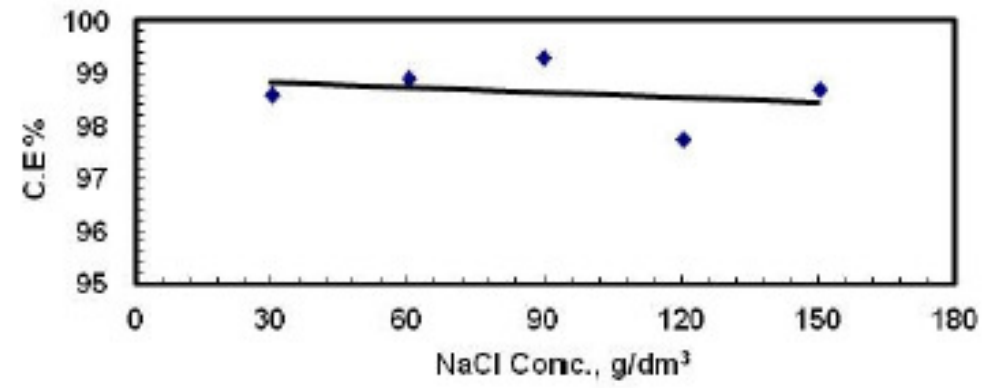

Figure 6. Effect of $\mathrm{NaCl}$ concentration on $\mathrm{CE}$.

\section{Effect of pH of the bath}

In order to investigate the effect of $\mathrm{pH}$ of the bath on the dissolution of zinc, four experiments were performed. Values of the $\mathrm{pH}$ of the bath were 7, 9, 11, and 13, while the following operating conditions were kept constant: concentration of $\mathrm{NaCl}=120 \mathrm{~g} / \mathrm{dm}^{3}$, applied potential $=5.5 \mathrm{~V}$, application of US, stainless steel cathode, and time of electrolysis $=120 \mathrm{~min}$.

Fig. 7 indicates that the dissolved zinc slightly decreased with increasing the $\mathrm{pH}$ of the bath. This decrease may be a result of the amphoteric nature of the produced $\mathrm{ZnO}$. Fig. 8 shows that the current efficiency was almost constant with increased $\mathrm{pH}$. These results indicate that the $\mathrm{pH}$ of the bath did not play a significant effect on the amount of the dissolved zinc or current efficiency at the range of $\mathrm{pH}$ covered. This may be approved by consulting Pourbaix diagram of zinc; as at the $\mathrm{pH}$ value of 7 , zinc oxide starts to form at a potential of $0.8 \mathrm{~V}$. The value of the potential, at which zinc oxide starts to form, decreases with increasing the $\mathrm{pH}$. Since the following work was carried out at higher values of potential than $0.8 \mathrm{~V}$, the effect of $\mathrm{pH}$ of the bath is minor.

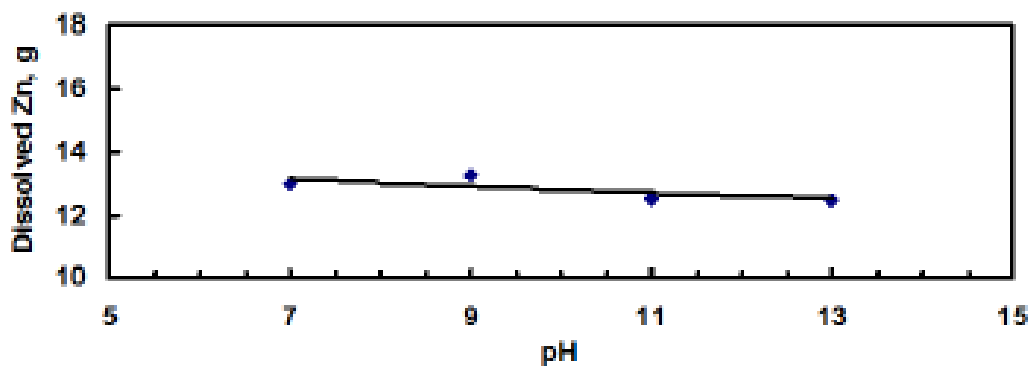

Figure 7. Effect of $\mathrm{pH}$ of the bath on the amount of zinc dissolved. 


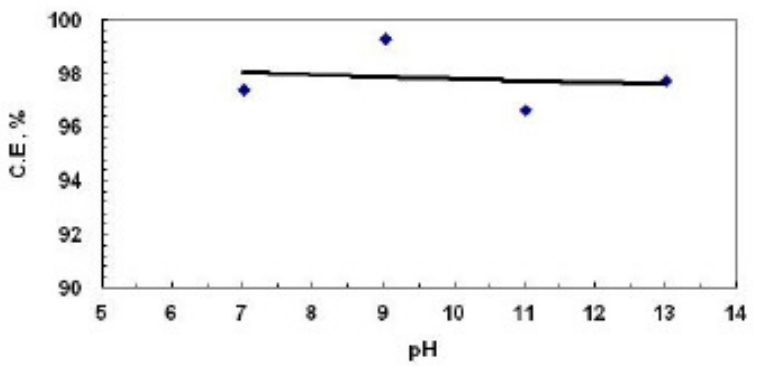

Figure 8. Effect of $\mathrm{pH}$ of the bath on $\mathrm{CE}$.

\section{Effect of solution temperature}

During the performance of experiments with the application of US waves, it was observed that at the end of an experiment the temperature of the electrolyte raised to a higher value than the starting temperature, which was about $25^{\circ} \mathrm{C}$. The final temperature was about $55{ }^{\circ} \mathrm{C}$ when the applied voltage was $5.5 \mathrm{~V}$. Therefore, it was necessary to investigate the effect of the temperature of the bath on anodic dissolution of zinc without the application of US waves.

The electrolytic cell was placed in a water bath and the temperature was adjusted either by heating or cooling. Cooling was done by adding ice and the temperature was closely monitored. Fig. 9 and 10 indicate that both the amount of dissolved zinc and $\mathrm{CE}$ increased with increasing temperature being the larger effect on the mass of dissolved zinc. Increasing the temperature from $10{ }^{\circ} \mathrm{C}$ to $40{ }^{\circ} \mathrm{C}$ led to a significant increase in the mass of the dissolved zinc; but the increase of temperature from 40 to $60{ }^{\circ} \mathrm{C}$, however, did not have a significant effect. This could be attributed to gas passivation.

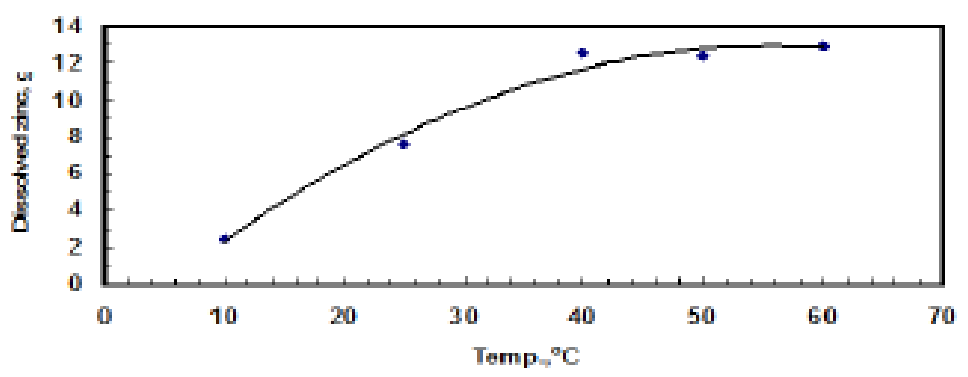

Figure 9. Effect of temperature on dissolved zinc.

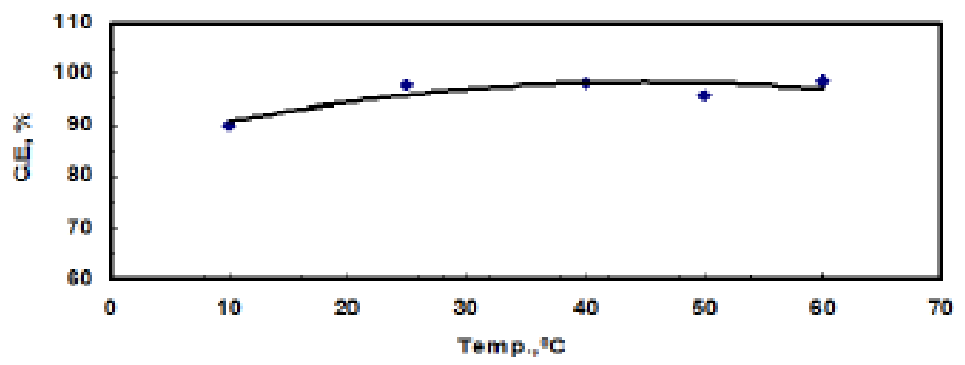

Figure 10. Effect of temperature on CE. 


\section{Conclusions}

1- The application of polarity reversal led to more dissolution of zinc but the current efficiency was low.

2- The application of ultrasonic enhancement led to higher zinc dissolution accompanied with higher CE.

3- The combination of ultrasonic enhancement and stirring led to more dissolution of zinc.

4- Increasing the current density increased the dissolution of zinc and the current efficiency was almost constant.

5- Increasing concentration of $\mathrm{NaCl}$ increased the dissolution of zinc, the current efficiency was almost constant.

6- $\mathrm{pH}$ of the bath did not play a significant effect on the amount of the dissolved zinc or current efficiency.

7- Increasing the temperature from $10{ }^{\circ} \mathrm{C}$ to $40{ }^{\circ} \mathrm{C}$ led to a significant increase in the mass of the dissolved zinc and $\mathrm{CE}$; however, the increase of temperature from $40{ }^{\circ} \mathrm{C}$ to $60{ }^{\circ} \mathrm{C}$ did not have a significant effect.

\section{References}

1. Buchel $\mathrm{KH}$, Moretto $\mathrm{H}-\mathrm{H}$, Woditsch $\mathrm{P}$. Industrial inorganic chemistry. WILEY-VCH; 2000

2. Patnaik P. Handbook of inorganic chemicals. McGraw Hill; 2003.

3. Buschow KHJ, Cahn R, Flemings M, et al. Encyclopedia of materials science and technology. Pergamon Press; 2001. Vol. 7.

4. Zhang XG. Corrosion and electrochemistry of zinc. New York: Plenum Press; 1996.

5. Porter FC. Zinc handbook: properties, processing, and use in design. New York: Marcel Dekker, 1991.

6. Murphy M. Metal Finishing. 1996;94:26.

7. Murphy M. Metal Finishing. 1997;95:28.

8. Abd El Aal EE. Anti-Corrosion Methods Mater. 1999;46:349.

9. El Rehim SSA, El-Sherbini EEF, Amin MA. J Electroanalytical Chem. 2003;560:175.

10. Armstrong RD, Bell MF. The electrochemical behaviour of zinc in alkaline solution. In: Thirsk HR, editor. Electrochemistry. The Royal Society of Chemistry, 1974: pp. 1-17.

11. Besseyrias A, Dalard F, Rameau JJ, et al. Corros Sci. 1997;39:1883.

12. Bounoughaz M, Salhi E, Benzine K, et al. J Mater Sci. 2003;38:1139.

13. Diomidis N, Celis JP. J Electrochem Soc. 2007;154:C711.

14. Flitt HJ, Schweinsberg DP. Corros Sci. 2010;52:1905.

15. El Sherbini EEF, El Rehim SSA. Corros Sci. 2000;42:785.

16. McBreen J, Cairns EJ. The zinc electrode. In: Gerischer H, Tobias CW, editors. Advances in electrochemistry and electrochemical engineering. New York: John Wiley \& Sons; 1978. p. 273.

17. Miao W, Cole IS, Neufeld AK, et al. J Electrochem Soc. 2007;154:C7.

18. Mouanga M, Berçot P. Corros Sci. 2010;52:3993. 
19. Mouanga M, Berçot P, Rauch JY. Corros Sci. 2010;52:3984.

20. Muralidharan VS, Rajagopalan KS. J Electroanal Chem Interfacial Electrochem. 1978;94:21.

21. Hampson NA, Herdman GA, Taylor R. J Electroanal Chem Interfacial Electrochem. 1970;25:9.

22. Bockris JO, Nagy Z, Danjanovic A. J Electrochem Soc. 1972:285.

23. Arise I, Fukunaka Y, McLarnon FR. J Electrochem Soc. 2006;153:A69.

24. Breiter MW. Electrochim Acta. 1971;16:1169.

25. Chang Y-C, Prentice G. J Electrochem Soc. 1989;136:3398.

26. Dirkse TP, Hampson NA. Electrochim Acta. 1972;17:387.

27. Dirkse TP, Hampson NA. Electrochim Acta. 1971;16:2049.

28. J. Hendrikx, A. van der Putten, W. Visscher, E. Barendrecht, The electrodeposition and dissolution of zinc and amalgamated zinc in alkaline solutions, Electrochim Acta. 1984;29:81.

29. Pyun S-I, Bae J-S, Park S-Y, et al. Corros Sci. 1994;36:827.

30. Chang Y-C. Electrochim Acta. 1996;41:2425.

31. Sato Y, Niki H, Takamura T. J Electrochem Soc. 1971;118:1269.

32. Powers RW, Breiter MW. J Electrochem Soc. 1969;116:719.

33. Armstrong RD, Bulman GM. J Electroanal Chem Interfacial Electrochem. 1970;25:121.

34. Assaf FH, El-Rehim SSA, Zaky AM. Brit Corros J. 2001;36:143.

35. Mokaddem M, Volovitch P, Ogle K. Electrochim Acta. 2010;55:7867.

36. El Rehim SSA, Fouad EE, El Wahab SMA, et al. J Electroanal Chem. 1996;401:113.

37. Schwabe K, Lück HB. Electrochim Acta. 1972;17:99.

38. Cachet C, Ganne F, Maurin G, et al. Electrochim Acta. 2001;47:509.

39. Cachet C, Ganne F, Joiret S, et al. Electrochim Acta. 2002;47:3409.

40. Cachet C, Wiart R. J Electroanal Chem. 1980;111:235.

41. Cachet C, Wiart R. J Electroanal Chem Interfacial Electrochem. 1981;129:103.

42. Velichenko AB, Portillo J, Sarret M, et al. Electrochim Acta. 1999;44:3377.

43. Giménez-Romero D, GarcIa-Jareño JJ, Vicente F. J Electroanal Chem. 2004;572:235.

44. Hefny MH, Babaqi AS, El-Basiouny MS, et al. Coll Czech Chem Comm. 1991;56:236.

45. Huajun Z, Zhenghai G, Jinhuan Z. Hydrometallurgy. 2007;89:369.

46. James WJ, Straumanis ME, Reed JL. The Office of Naval Research. Technical Report \#10 (Contract No 2296 (03)); 1964.

47. Johnson JW, Son YC, James WJ. Corros Sci. 1971;11:153.

48. Menzies IA, Marshall GW, Gearey D, et al. J Electrochem Soc. 1970;117:849.

49. Stankovic S, Grgur B, Krstajic N. et al. J Serb Chem Soc. 2003;68:207.

50. Abd El Aal E. Corros Sci. 2006;48:343.

51. Aliev ZM, Vladimirova MV, Kharlamova TA, et al. Russ J Appl Chem. 2002;75:50.

52. Rangel CM, Cruz LF. Corros Sci. 1992;33:1479. 
53. Qu Q, Li L, Bai W, et al. Corros Sci. 2005;47:2832.

54. Kalinauskas P, Valsiunas I, Samuleviciene M, et al. Corros Sci. 2001;43:2083.

55. Chen ZY, Persson D, Leygraf C. Corros Sci. 2008;50:111.

56. Suslick KS. Science. 1990;247:1439.

57. Compton RG, Eklund JC, Marken F, et al. Electrochimica Acta. 1997;42:2919.

58. Amin MA. Electrochim Acta. 50 (2005) 1265. 